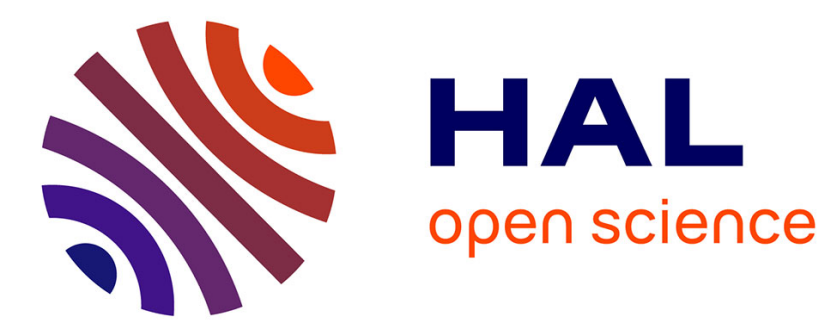

\title{
English cum, a borrowed coordinator turned complex-compound marker
}

\author{
Vincent Renner
}

\section{To cite this version:}

Vincent Renner. English cum, a borrowed coordinator turned complex-compound marker. Morphology, 2013, 23 (1), pp.57-66. hal-00966585

\section{HAL Id: hal-00966585 \\ https://hal.science/hal-00966585}

Submitted on 26 Mar 2014

HAL is a multi-disciplinary open access archive for the deposit and dissemination of scientific research documents, whether they are published or not. The documents may come from teaching and research institutions in France or abroad, or from public or private research centers.
L'archive ouverte pluridisciplinaire HAL, est destinée au dépôt et à la diffusion de documents scientifiques de niveau recherche, publiés ou non, émanant des établissements d'enseignement et de recherche français ou étrangers, des laboratoires publics ou privés. 


\title{
English cum, a borrowed coordinator turned complex-compound marker
}

Vincent Renner

\begin{abstract}
This article takes issue with the traditional view of English compounds such as governess-cumpiano-teacher, according to which the medial morpheme -cum-is insignificant. The study is first centered on the appearance of the linking element in the English language. New insight into its distribution and function is then provided by scrutinizing a list of 259 compounds extracted from a present-day newspaper corpus. It is found that -cum-appears exclusively in non-institutionalized coordinate nominal and adjectival compounds and that it plays a distinctive role which sets -cumcompounds apart from asyndetic compounds: the linking element is predominantly used in complex compounds to simultaneously mark the internal boundary (boundaries) within the construction and the coordinate relation that holds between the compounding elements. The discussion finally focuses on the status of -cum-, which appears to be a hybrid syntactic-morphological unit of present-day English.
\end{abstract}

Keywords English, Compounding, Linking element, Coordination

\section{Introduction}

Cum is an intriguing grammatical morpheme of present-day English. It is not mentioned in standard reference grammars such as A comprehensive grammar of the English language (Quirk et al. 1985) and the Cambridge grammar of the English language (Huddleston and Pullum 2002) and it is treated with inconsistency by lexicographers. Some dictionaries (e.g. the Compact Oxford English Dictionary of Current English and the American Heritage Dictionary of the English Language) label it a preposition even when used in a medial position, as in poet-cum-philosopher and emotional-cum-intellectual, but another (the Merriam-Webster's Online Dictionary) considers that it is a conjunction. In several dictionaries (e.g. the Cambridge Advanced Learner's Dictionary and the Collins COBUILD Advanced Learner's English Dictionary), its medial status is made graphically explicit, the entry form appearing with a hyphen on either side: "-cum-". In the specialized literature, -cum- has received scant attention, with the exception of two studies, one by Burnham (1955), who briefly documents its appearance in American English in the first half of the twentieth 
century, and another by Stein (2000), who discusses its treament in various late twentieth-century dictionaries. Stein claims that -cum-:

- is not a free coordinating conjunction, but a bound morpheme which is clearly neither a prefix, nor a suffix;

- is a marker of grammatical and semantic subordination: in an $X$-cum- $Y$ compound, $\mathrm{Y}$ is used to delineate a subset of the class of Xs - a butler-cum-chauffeur is a kind of butler and a pub-cum-hotel a kind of pub;

- is used in compounds which are temporary coinages used to denote unfamiliar objects, relations, or qualities.

Cum is a prepositional borrowing from Latin which has made its way into the phraseology of English through a very limited number of mock-Latin phrases belonging to the terminology of finance (cum coupon, cum dividend, cum drawing, cum new, cum rights), but it has not made its way into its syntax - cum cannot, for instance, freely introduce or coordinate phrases as with or and can -, so describing it as a preposition or conjunction of the English language is debatable. Cum's only productive use in present-day English is as a bound morpheme which may only appear between two lexemes and it therefore fits the definition of the interfix as given by Mel'čuk (2000: 528, 2006: 299-300), that is a confix ${ }^{1}$ which follows a root and necessarily precedes another one, as in German Liebe+s+brief, "love+INTERFIX+letter", or Russian beton+o+meshalka, "concrete +INTERFIX+mixer". Yet, cum immediately stands out as atypical, in part because it is never graphically blended with the lexemes immediately next to it: hyphenated spelling is the preferred form and, remarkably, it is sometimes unhyphenated, that is graphically free-standing. As its exact nature (morphological or syntactic) cannot be clearly settled (see Section 4 below), I will avoid using the terms interfix and conjunction and will refer non-committally to cum as a linking element (or linker for short) in the rest of the article. This term is used in the linguistic literature to denote semantically empty elements which bind together the constituents of a compound, and its use is sometimes extended to prepositions such as French de or $\grave{a}$ on account of the fact that, when used in noun-preposition-noun constructions such as village de vacances lit. "village of holiday" ('holiday village') and masque à gaz lit. "mask for gas" ('gas mask'), these elements do not retain their full

\footnotetext{
${ }^{1}$ A confix is a type of affix whose defining feature is that it does not interrupt a root and is not interrupted by a root. Depending on the position vis-à-vis the root(s), three types of confixes are distinguished: prefixes, suffixes and interfixes.
} 
denotation and sometimes coexist with prepositionless variants. ${ }^{2}$ The use of the term linking element in the sections to follow does not imply, however, that -cum- should be regarded as a semantically empty element, as will be detailed in Sections 3 and 4.

This study aims to shed new light on the origins, the distribution, the function and the status of -cum-. It will notably provide valuable insight into its current use in compounding by analyzing an extensive list of present-day constructions which were collected from the Guardian Unlimited online newspaper archive. The structure of the article is as follows: in Section 2, I will first trace the appearance of cum in the English language; in Section 3, I will turn to the distribution and the function of the linker, focusing on the formal and semantic characteristics of -cum-compounds and eliciting its functionalization in present-day English; finally, in Section 4, I will discuss its hybrid status, which appears to be neither prototypically morphological, nor prototypically syntactic.

\section{Elements of the English history of cum}

Information on the historical origins of English cum can be found in the Oxford English Dictionary, which states that the morpheme is originally a "Latin preposition, meaning 'with, together with', used in English in local names of combined parishes or benefices, as Chorlton-cum-Hardy, Stowcum-Quy, where it originated in Latin documents". Diachronic data up to the twentieth century are extremely scarce, but the use of -cum- in English place-name compounds is attested from the fourteenth century onwards, as is the case, for example, of Stow-cum-Quy (Wareham and Wright 2002: 230):

Though having separate manors, [Quy and Stow] were combined as one ecclesiastical parish by the early $13^{\text {th }}$ century and treated administratively as a single vill by the late $13^{\text {th }}$. From the early $14^{\text {th }}$ century they were regularly styled Stow cum Quy or Stow Quy.

The appearance of cum outside parochial toponymy is hard to pinpoint. It can be conjectured that it happened in the nineteenth century as the $X$-cum- $Y$ template has been attested since the midnineteenth century, as the following early quotations testify: ${ }^{3}$

\footnotetext{
${ }^{2}$ For a discussion on French, see Kampers-Manhe 2001 and Nicoladis 2002.

${ }^{3}$ These early occurrences of -cum- compounding have been retrieved from the Google Book Search database, which is available at: http://books.google.com (accessed 23 September 2011).
} 
- 1853: "the cup of coffee-cum-chicory" (Lectures delivered before the Young Men's Christian Association, in Exeter Hall, from November 1852, to February 1853, London, James Nisbet);

- 1871: "life in Belgravia-cum-Pimlico" (Anthony Trollope, The Eustace Diamonds, The Fortnightly Review, volume 16);

- 1888: "a goods-cum-booking-office-cum-parcels-clerk" (Rudyard Kipling, Letters of Marque, Chapter IX, The Pioneer, 12 January 1888);

- 1905: "a court of ultimate appeal-cum-meteorological bureau" (Rudyard Kipling, With the Night Mail, The Windsor Magazine, volume 23 (1)).

As documented by Burnham (1955), the use of -cum- compounds crossed the Atlantic in the first half of the twentieth century and has now spread widely, if not prominently, in American English as well.

\section{The distribution and function of the linker}

The corpus of investigation is comprised of all the -cum- compounds occurring in the 2006 Guardian Unlimited online archive. ${ }^{4}$ The linking element appears in 259 compounds, 251 of which occur only once in the corpus, ${ }^{5}$ which shows that the $X$-cum- $Y$ pattern is productive. As noted by Burnham (1955) and Stein (2000), -cum- only appears in novel compounds, with the possible exception of one noun. The compound cross-cum-shot occurs six times in the corpus and is used by four different journalists. It might therefore be considered as belonging to the terminology of soccer, and would be a variant of the asyndetic compound cross-shot, which is seven times more frequent in the same corpus.

The linker is a coordination marker and -cum- compounds are coordinate compounds. The compounding elements are cohyponyms whose linear order is not grammatically constrained. This

\footnotetext{
${ }^{4}$ The archive contains the full text of The Guardian, The Observer, The Guardian Weekly and the guardian.co.uk website. It is available at http://www.guardian.co.uk/search (accessed 23 September 2011).

${ }^{5}$ Chairman-cum-manager, house-cum-studio and installation-cum-performance occur twice and cross-cumshot occurs six times in the corpus.
} 
last characteristic is illustrated in the corpus: a same denotatum is referred to by an $X$-cum- $Y$ compound in one article and by a $Y$-cum-X compound in another: "the Sunderland chairman cum manager" / "Sunderland's new manager-cum-chairman". Constituent ordering is influenced by the difference in contextual salience between the compounding elements and by a syllable number constraint. The distribution of the binary compounds of the corpus between those constructions with a longer left constituent (e.g. anthropologist-cum-translator, information hub-cum-cafe) and those with a longer right constituent (e.g. ontological-cum-epistemological, governess-cum-pianoteacher $)$ is statistically highly significant: the former are 67 , the latter $110\left(\chi^{2}(1)=10.4 ; p\right.$ $<0.0013)$.

Cum is overwhelmingly used to link nouns as 247 out of 251 compounds or 98.4 percent of all occurrences are nominal. Seventeen or 6.9 percent of these 247 nominal compounds are embedded, i.e. subordinated to a head noun, as in London cum Yorkshire accent, reggae-cum-rap artist and synth-pop-cum-indie-rock hybrid debut. As shown by Renner (2008: 608-609), English nominal coordinate compounds can be divided into three semantic classes on the basis of two features, semantic headedness and the referential relation between the denotata of the compounding elements: multifunctionals such as hunter-gatherer and fighter-bomber are double-headed compounds with fused denotata, hybrids such as gum resin and troutperch are unheaded compounds with fused denotata, and additionals such as tractor-trailer and dinner dance are unheaded compounds with unfused denotata. The identification of the three classes can also be operationalized through the use of test sentences. The tripartite division brings to light that a great majority of -cum- compounds belong to the same class:

- 83.4 percent are multifunctional, i.e. are best inserted in the test sentence "an $X$-cum-Y is an $X$ who/which is also a $Y^{\prime \prime}$ (e.g. girlfriend-cum-muse, library-cum-torture chamber, walking tour-cum-photography masterclass);

- 9.3 percent are hybrid, i.e. are best inserted in the test sentence "X-cum-Y is a hybrid form of $X$ and $Y^{\prime \prime}$ (e.g. live-action-cum-animation, disco-cum-reggae-cum-bubblegum pop [makeover]);

- 3.6 percent are additional, i.e. are best inserted in the test sentence "an X-cum-Y is an X plus a Y" (e.g. orchard-cum-distillery, sale-cum-distribution); 
- 3.6 percent are undetermined as context cannot always dispel ambiguity, as in reggae-cumrap artist, a compound with two possible readings: "an artist singing reggae music and rap music" and "an artist singing a hybrid form of music which is halfway between rap music and reggae music".

The distribution is even more unbalanced if embedded and non-embedded compounds are distinguished. Embedded compounds are split about evenly between additionals (e.g. assessmentcum-teaching cycles, circulation-cum-distribution figure), hybrids (e.g. London cum Yorkshire accent, synth-pop-cum-indie-rock hybrid debut) and multifunctionals (e.g. dominatrix-cum-stable boss outfit, stunted child-cum-sex-pest shtick) whereas non-embedded compounds are overwhelmingly multifunctional (203 items out of 230 or 88.3 percent). This last fact sharply differentiates -cum- constructions from binomials such as bow and arrow and mom-and-pop, which overwhelmingly code semantically additional units (Renner 2006: 200-201).

The four remaining compounds of the corpus are adjectival: ontological-cum-epistemological, sweet-cum-savoury, sinister-cum-romantic and friendly-cum-aggressive. English adjectival coordinate compounds can be divided into two semantic categories (Renner 2008: 610): additionals such as deaf-blind and pale-dry, which are best inserted in the test sentence "To be $X$-Y is to be $X$ and to be $Y^{\prime \prime}$, and hybrids such as blue-green and medium-rare, which are best inserted in the test sentence "To be X.Y is to be about midway between $X$ and $Y$ "; the four -cum- compounds unambiguously belong to the former category.

Corpus data also indicate that -cum- compounds are predominantly constructions which result from assembling either two multilexemic compounding elements (e.g. hip-hop mogul cum social rights campaigner, celebrity fire-fighting comic soapstar-cum-cultural commentator) or more than two monolexemic compounding elements (e.g. celebration-cum-critique-cum-parody, driver-cumwaiter-cum-porter-cum-sommelier) whereas the vast majority of English compounds are bilexemic constructions. Only 44.6 percent of nominal -cum- compounds conform to the prototypical form of English compounding, i.e. the association of two lexemes into a compound. Constituents of different syntactic status may enter the construction - the noun-cum-NP (e.g. man-cum-less-thanjolly-green-giant), NP-cum-noun (e.g. forensic anthropologist-cum-thriller writer) and NP-cum-NP (e.g. school of kitchen-discipline-cum-theatre-of-cruelty) patterns are all attested - and the 251 
compounds under study may be categorized into 23 structural templates which are exemplified below to illustrate the great plasticity of the construction: ${ }^{6}$

i. binary compounds

- 1+1 (112): grave-cum-shrine, lover-cum-husband, sorrow-cum-scepticism.

- 1+2 (53): nursery-cum-kids' club, addict-cum-narcotics-detective.

- 1+3 (3): documentary-cum-campaign-water-tester, thriller-cum-retrospective love story.

- 1+4 (1): Serps-cum-stakeholder earnings-related pension.

- 1+5 (1): man-cum-less-than-jolly-green-giant.

- 2+1 (24): film-maker-cum-propagandist, laurel bush-cum-loo, sleeping bag cum coffins.

- 2+2 (25): cab driver-cum-television consultant, character study-cum-crime thriller.

-2+3 (11): computer shop-cum-video game arcade, keyboard players-cum-black-boxtriggerers.

- 2+4 (1): barber-surgeons-cum-serial-throat-slashing cannibals.

- 3+1 (1): Rocky Horror Show-cum-panto.

- 3+2 (4): multi-arts centre cum squat party, second-home complex-cum-nature reserve.

- 3+4 (1): 4-5-1 cum 4-4-1-1 [system].

- 4+2 (1): itinerant South American guitarist-cum-lethal gunman.

- 4+3 (1): school of kitchen-discipline-cum-theatre-of-cruelty.

-5+2 (2): celebrity fire-fighting comic soapstar-cum-cultural commentator, hand-carved wooden tree-thing-cum-hat-stand.

ii. ternary compounds

- 1+1+1 (2): celebration-cum-critique-cum-parody, memoir-cum-history-cum-rant.

- 1+1+2 (1): disco-cum-reggae-cum-bubblegum pop [makeover].

- 1+2+3 (1): heiress-cum-TV presenter-cum-aspirant pop star.

-2+1+1 (2): chocolate shop-cum-patisserie-cum-cafe, surf shack cum hostel cum bar.

- 2+1+3 (1): fashion-designer-cum-writer-cum-women's-rights campaigner.

- 3+1+3 (1): stand-up comedians cum breakdancers cum Lionel Richie devotees.

\footnotetext{
${ }^{6}$ In the formulas, the '+' sign symbolizes the linker and the adjacent digits the number of words on either side of the linker; the total number of compounds exemplifying each template in the corpus is then given in parentheses.
} 
iii. quaternary compounds

- 1+1+1+1 (1): driver-cum-waiter-cum-porter-cum-sommelier.

- 1+1+1+2 (1): restaurant-cum-brasserie-cum-delicatessen-cum-cookery school.

The use of -cum- is often said to add an intellectual and/or humorous tinge to the compound, but this idea is not clearly borne out by the corpus data, which, it should be noted, are limited to the semi-formal journalistic style. This is most probably due to the fact that, in many compounds, -cumplays a different role. The functionalization of the linker gradually becomes apparent as the number and variety of complex templates observed in the corpus of examples grow. In the case of the association of only two lexemes into a compound, as in singer-cum-thespian or brasserie-cum-bar, the absence of the linking element will not hinder the interpretation of the compound, ${ }^{7}$ but with the association of three or more lexemes, the interpretation of the internal structure is potentially uncertain, and the presence of -cum- immediately dispels ambiguity. This can be illustrated by a compound taken from the corpus: the four-noun construction documentary campaign water tester is equivocal - it may denote a water tester for a documentary campaign, a documentary campaign which is also a water tester or a documentary which is also a campaign water tester -, but documentary-cum-campaign-water-tester is not - a documentary-cum-campaign-water-tester is a documentary which is also a campaign water tester. The presence of -cum-instantly unveils the internal structure of the compound by graphically marking its internal boundary (boundaries) while at the same time the linker codes the semantic relation which holds between the members. This relation is coordinate; the linker indicates that the structure is semantically flat, non-hierarchical, unlike prototypical compounds in English, which are right-headed. The possibility of overtly signaling the coordinate status of a compound is not trivial as coordinate compounds are relatively infrequent (Arnaud (2002: 4) and Berg (2009: 134) both estimate that only about 2 percent of English noun-noun compounds are of the coordinate type); the presence of -cum-is conjectured to serve to immediately activate the marked interpretation (in terms of frequency) of the compound. At a more general level, the linking element is hypothesized to have been partially functionalized in order to facilitate the processing of complex coordinate compounds, alleviating the parsing load of the hearer/reader. This functionalization into a marker of immediate constituent structure is not unique to English - linking elements in other Germanic languages, such as Swedish (Mellenius

\footnotetext{
${ }^{7}$ This claim is untrue for two compounds of the corpus, executive-cum-producer and novel-cum-memoir. If the two lexemes were to be juxtaposed, the left constituent might be interpreted as an adjective.
} 
1997), German and Danish (Kürschner 2003), have developed the same role -, but the singularity of -cum- lies in the fact that it has both a morphological and a semantic function.

\section{The status of the linker}

Cum is an atypical case of a linking element. It did not originate from an earlier inflectional ending, as is usually the case in other Germanic languages, or from the syntax as it is a borrowing which has never been part of the syntax of English. Its status is unclear as it is neither a prototypical interfix, nor a prototypical coordinating conjunction. Unlike prototypical interfixes, which have the shape of either a rime or a coda (Dressler and Merlini Barbaresi 1991: 141), -cum- is prosodically syllabic. Moreover, it only occurs in non-solid compounds (i.e. compounds that are spelled with hyphens or spaces) whereas an interfix is normally graphically blended ${ }^{8}$ in the corpus, the linking element is accompanied by hyphens on either side, with the exception of 26 items, or about 10 percent of all occurrences, in which it is isolated by spaces. Finally, unlike prototypical interfixes, which are empty affixes (Bauer 2004: 57, Haspelmath \& Sims 2010: 332), the linker is not semantically empty; it is a coordination marker. Mel'čuk (1997: 150) stresses that interfixes are not by definition meaningless, and even though he has no example at hand, he contemplates the possible existence of interfixes that would signal the semantic relation which holds between the compounding elements, which is precisely what -cum- does. On the other hand, unlike prototypical coordinating conjunctions, which can be omitted in multiple coordination if they do not link the last two coordinands (Haspelmath 2004: 5), -cum- is only used recursively, as in driver-cum-waiter-cumporter-cum-sommelier; monosyndesis is unacceptable (*driver-waiter-porter-cum-sommelier). Cum compounds are syntactic in their plural marking as a double plural is the norm - in the corpus, 19 out of 20 plural forms are doubly marked (e.g. columnists-cum-bloggers, villages cum beach resorts) -, but they display a conspicuous non-syntactic property: the use of the linker is restricted to the combination of nouns or adjectives; verbal (e.g. ??freeze-cum-dry, ??drink-cum-drive) and adverbial (e.g. ??jointly-cum-severally, ??purely-cum-simply) compounds are not attested. In conclusion, -cum- is best described as a hybrid linker at the morphology-syntax boundary, -cumcompounds as intermediate objects between prototypical morphological and syntactic constructions.

According to the Oxford English Dictionary, cum was used as a coordinator in the Medieval Latin of England, at least in onomastics, in the coinage of names of dual parishes. Strictly speaking, it

\footnotetext{
${ }^{8}$ There are other exceptions, such as English junk-a-holic and cock-a-poo, which are attested spellings in the Corpus of Contemporary American English (http://corpus.byu.edu/coca, accessed 23 September 2011).
} 
cannot be said that it was cum that was adopted into English; the denominations of the parishes simply happened to be used in English just as they were in Latin. For centuries, the $X$-cum- $Y$ template was available for toponyms only. In the nineteenth century, for some still unknown reason, it was activated for use outside onomastics and rapidly gave rise to complex structures never attested in toponymy - e.g. goods-cum-booking-office-cum-parcels-clerk (coined by Kipling in 1888) -, which hints at the fact that, soon after the template's use was extended to appellatives, some speakers elaborated upon the original template to disambiguate multilexemic compounds. In the light of this singular history, as the place of -cum- among linking elements happens to be very peripheral, the term linking element might be considered to be somewhat misleading and another term might be useful. Present-day English -cum- could be denominated a compound marker - a term which Ralli (2008) uses to refer to any semantically empty morpheme whose primary function is to indicate the process of compound formation - and, when functionalized into a disambiguator, a complex-compound marker.

\section{Conclusion}

This study has provided fresh insight into a largely neglected morpheme of present-day English. The presence of -cum- in place-name compounds is attested from the fourteenth century, and the linker has been used in appellative compounding at least since the mid-nineteenth century. It is best described as a hybrid linking element, with both morphological and syntactic properties. It appears exclusively in non-institutionalized coordinate nominal and adjectival compounds, the overwhelming majority of which are multifunctional nouns, and it plays a distinctive role which sets -cum- compounds apart from asyndetic compounds: the linking element is predominantly used in complex compounds to simultaneously mark the internal boundary (boundaries) within the construction and the coordinate relation that holds between the compounding elements.

\section{Acknowledgments}

Earlier versions of this research were presented at the University of Avignon in May 2007 and the University of Vienna in February 2008. I am grateful to the two audiences for their feedback and suggestions. My thanks also go to Gabriele Stein, to the anonymous reviewers and to the guesteditors, Renata Szczepaniak and Sebastian Kürschner, for stimulating comments and detailed recommendations. The usual disclaimers apply. 


\section{References}

Arnaud, P. J. L. (2002). Document de travail sur les noms composés anglais. Unpublished manuscript. Université Lumière Lyon 2.

Bauer, L. (2004). A glossary of morphology. Edinburgh: Edinburgh University Press.

Berg, Th. (2009). Structure in language, a dynamic perspective. New York: Routledge.

Burnham, J. M. (1955). An imported fashion. American Speech, 30 (3). 222-223.

Dressler, W. U., \& Merlini Barbaresi, L. (1991). Interradical interfixes: contact and contrast. In V. Ivir, \& D. Kalogjera (Eds.), Languages in contact and contrast: essays in contact linguistics (pp. 133-145). Berlin: Mouton de Gruyter.

Haspelmath, M. (2004). Coordinating constructions: an overview. In M. Haspelmath (Ed.), Coordinating constructions (pp. 3-39). Amsterdam: Benjamins.

Haspelmath, M., \& Sims, A. D. (2010). Understanding morphology, second edition. London: Hodder Education.

Huddleston, R., \& Pullum, G. K. (2002). The Cambridge grammar of the English language. Cambridge: Cambridge University Press.

Kampers-Manhe, B. (2001). Le statut de la préposition dans les mots composés. Travaux de linguistique, 42-43 (1-2). 97-109.

Kürschner, S. (2003). Von Volk-s-musik und Sport-ø-geist im Lemming-ø-land - Af folk-e-musik og sport-s-ånd $i$ lemming-e-landet: Fugenelemente im Deutschen und Dänischen - eine kontrastive Studie zu einem Grenzfall der Morphologie. Freiburg im Breisgau: University of Freiburg's FreiDok archives. http://www.freidok.uni-freiburg.de/volltexte/1256/pdf/Kuerschner_ Fugenelemente_MagArbeit.pdf. Accessed 23 September 2011.

Mel'čuk, I. A. (1997). Cours de morphologie générale, volume 4, cinquième partie: signes morphologiques. Montréal: Presses de l'Université de Montréal.

Mel'čuk, I. A. (2000). Morphological processes. In G. E. Booij, Ch. Lehmann, \& J. Mugdan (Eds.), Morphology, a handbook on inflection and word formation, volume 1 (pp. 523-535). Berlin: de Gruyter.

Mel'čuk, I. A. (2006). Aspects of the theory of morphology. Berlin: de Gruyter.

Mellenius, I. (1997). The acquisition of nominal compounding in Swedish. Lund: Lund University Press.

Nicoladis, E. (2002). When is a preposition a linking element? Bilingual children's acquisition of French compound nouns. Folia linguistica, 36 (1-2). 45-63.

Quirk, R., Greenbaum, S., Leech, G., \& Svartvik, J. (1985). A comprehensive grammar of the English language. Harlow: Longman. 
Ralli, A. (2008). Compound markers and parametric variation. STUF - Language typology and universals, 61 (1). 19-38.

Renner, V. (2006). Les composés coordinatifs en anglais contemporain. $\mathrm{PhD}$ dissertation. Université Lumière Lyon 2. http://tel.archives-ouvertes.fr/docs/00/56/50/46/PDF/Renner 2006.pdf. Accessed 23 September 2011.

Renner, V. (2008). On the semantics of English coordinate compounds. English Studies, 89 (5). 606-613.

Stein, G. (2000). The function of word-formation and the case of English -cum-. In Ch. DaltonPuffer, \& N. Ritt (Eds.), Words: structure, meaning, function, a festschrift for Dieter Kastovsky (pp. 277-288). Berlin: Mouton de Gruyter.

Wareham, A. F., \& Wright, A. P. M. (2002). Stow cum Quy. In A history of the county of Cambridge and the Isle of Ely: volume 10 - Cheveley, Flendish, Staine and Staploe Hundreds (north-eastern Cambridgeshire) (pp. 230-233). Woodbridge, Suffolk: Boydell \& Brewer. http://www.british-history.ac.uk/report.aspx?compid=18862. Accessed 23 September 2011.

\section{Dictionaries}

American Heritage Dictionary of the English Language, fourth edition (2000). Boston: Houghton Mifflin.

Cambridge Advanced Learner's Dictionary, third edition (2008). Cambridge: Cambridge University Press.

Collins COBUILD Advanced Learner's English Dictionary, fourth edition (2003). Glasgow: HarperCollins.

Compact Oxford English Dictionary of Current English, second edition (2001). Oxford: Oxford University Press.

Merriam-Webster's Online Dictionary. http://www.merriam-webster.com. Accessed 23 September 2011.

Oxford English Dictionary Online. http://www.oed.com. Accessed 23 September 2011. 